\title{
ANTIBACTERIAL ACTIVITY OF POLYSCIAS SCUTELLARIA FOSBERG AGAINST ACINETOBACTER SP.
}

\author{
DELA ROSA ${ }^{1 *}$, YUNIWATY HALIM ${ }^{2}$, NATANIA KAM ${ }^{2}$, MARCELIA SUGATA ${ }^{1}$, ARIELA SAMANTHA ${ }^{1}$ \\ ${ }^{1}$ Department of Biology, Universitas Pelita Harapan, Tangerang, Indonesia. ${ }^{2}$ Department of Food Technology, Universitas Pelita Harapan, \\ Tangerang, Indonesia. Email: dela.rosa@uph.edu
}

Received: 15 October 2018, Revised and Accepted: 14 December 2018

\section{ABSTRACT}

Objective: Polyscias scutellaria Fosberg as one of the indigenous plants from Indonesia has been used as traditional medicines for several ailments, such as reduce body odor. However, there is no scientific research to verify this property. This study aimed to evaluate the antibacterial activity of P. scutellaria Fosberg against bacteria that cause body odor.

Methods: Since body odor is caused by activities of bacteria that live in the armpits, bacteria from human armpit were isolated and identified as Acinetobacter sp. The bacteria have the potential to be pathogenic and resistant to common antibiotics. $P$. scutellaria was extracted using different solvents, i.e., hexane, ethyl acetate, and methanol. Using these extracts, the antibacterial activity of P. scutellaria against Acinetobacter sp. was tested through well diffusion and colony-forming unit methods.

Results: Hexane and ethyl acetate fractions of P. scutellaria extract showed strong antibacterial activities against Acinetobacter sp., while methanol fraction did not exhibit any antibacterial activity against these bacteria.

Conclusion: P. scutellaria extract has the potential to be used as an antibacterial agent against Acinetobacter sp. on human armpit.

Keywords: Acinetobacter sp., Antibacterial, Nothopanax scutellarium, Polyscia s scutellaria.

(C) 2019 The Authors. Published by Innovare Academic Sciences Pvt Ltd. This is an open access article under the CC BY license (http://creativecommons. org/licenses/by/4. 0/) DOI: http://dx.doi.org/10.22159/ajpcr.2019.v12i1.30270

\section{INTRODUCTION}

As a tropical country with the second largest biodiversity in the world, Indonesia is a home of more than 40,000 plant species where about $10 \%$ of them are medicinal plants. Conducted research results have shown antiviral, antibacterial, antifungal, and antiparasitic activities of those plants [1]. However, only about 200 plants were studied. The very small number of plants studied compared to an overall number of medicinal plants creates opportunities for further explorations and studies about the biological properties of Indonesian medicinal plants [2].

Polyscias scutellaria Fosberg (also known as Nothopanax scutellarium Merr) is one of the indigenous plants from Indonesia which has long been used as traditional medicine to treat breast inflammation, wounds, urinary tract problem, and body odor $[3,4]$. The traditional use of $P$. scutellaria Fosberg to treat body odor suggested that this plant has antibacterial properties. The hypothesis arises from the finding that volatile odorous molecules, which cause body odor, are produced through biotransformation of odorless body secretions by human axilla microbiota [5].

Human armpits, which are one of the human skin regions that are partially covered, are warm and moist, and therefore suitable for the growth of microorganisms. Most of the microorganisms which inhabit human skins are harmless and even provide protection against pathogenic bacteria [6]. However, Acinetobacter sp., which are frequently isolated from moist regions of human skin and formerly known as commensal bacteria, have somehow evolved into pathogenic bacteria and caused outbreaks in intensive care unit $[7,8]$. Acinetobacter sp. are found to be resistant to all existing antibiotic classes and even show great ability to acquire new resistance [9]. This situation creates urgency for the development of new antibacterial as a treatment against multidrug-resistant Acinetobacter sp. [10]. This study investigated the antibacterial activity of P. scutellaria Fosberg extracts against Acinetobacter sp. isolated from healthy human armpit skin.

\section{MATERIALS AND METHODS}

\section{Materials}

Sample of $P$. scutellaria was obtained from Tangerang, Indonesia, and has been identified by Pusat Konservasi Tumbuhan Kebun Raya Bogor (Center for Plant Conservation, Bogor Botanical Garden). For human armpit bacteria isolation, samples were taken from donor in Tangerang, Indonesia. Bacteria growth medium was blood agar, using sheep blood obtained from Universitas Indonesia, while the nutrient agar and broth used were from Merck. Dimethyl sulfoxide (DMSO) was obtained from Merck and used as a solvent for some of the experiments.

\section{Extraction of active compound from $P$. scutellaria}

The extraction procedure was a modified version of the method reported by Irulandi et al. [11]. The leaf samples of $P$. scutellaria were dried using the oven at temperature $50^{\circ} \mathrm{C}$ for $10 \mathrm{~h}$, resulting in $400 \mathrm{~g}$ of dried samples. The dried samples were then macerated for $24 \mathrm{~h}$ using $6 \mathrm{l}$ of hexane as solvent at room temperature. The result of this maceration was referred as hexane fraction. Consecutive maceration of the dried samples was done for $24 \mathrm{~h}$ using $6 \mathrm{l}$ of ethyl acetate as a solvent, producing ethyl acetate fraction. The last maceration of the dried samples using $6 \mathrm{l}$ of methanol was done to obtain methanol fraction. All procedures were done twice. The solvent in all fractions was evaporated using rotary evaporator at a temperature of $60^{\circ} \mathrm{C}$.

\section{Collection of bacteria consortium from donor's armpit}

Armpit swab of a male donor (30 years old, daily user of deodorant) was collected. Before collecting the bacteria consortium, the donor was instructed not to use deodorant for at least $24 \mathrm{~h}$. Following the regular procedure [12], the sterile swab stick was moistened with $1.0 \mathrm{ml}$ of 
sterile phosphate buffer saline (pH 7.4), and rubbed in a circular motion over the armpits of the donor.

\section{Isolation of bacteria from human armpit}

Blood base agar medium (Merck) was made by adding $7 \%$ sheep red blood cells (sRBC) to the base agar. SRBC was obtained from Universitas Indonesia. The swab was inoculated immediately after collection onto the surface of the medium in the Petri dish. The culture was incubated at $37^{\circ} \mathrm{C}$ for $24 \mathrm{~h}$. After incubation, several colonies observed were picked based on the differences on their colony morphology to be purified using four-way steak method [12]. The growing bacterial isolates were identified and characterized. The methods used are based on cell morphology (using Gram staining), the capability to produce endospore (using endospore-staining), and various biochemical tests such as mannitol and glucose fermentation, indole, starch, and gelatin hydrolysis as well as catalase test. The capability of bacterial isolates to grow at several temperatures $\left(37^{\circ} \mathrm{C}, 40^{\circ} \mathrm{C}, 42^{\circ} \mathrm{C}\right.$, and $\left.44^{\circ} \mathrm{C}\right)$ was also observed.

\section{Molecular identification of bacteria}

The genome of bacterial isolate was extracted using Wizard® Genomic DNA Purification Kit (Promega). The 16S rRNA gene was amplified using PCR. The polymerase chain reaction (PCR) primer used was forward primer 27F (5' AGAGTTTGATCMTGGCTCAG 3') (IDT Inc., Singapore) and reverse primer 1492R (5' TACGGYTACCTTGTTA CGACTT 3') (IDT Inc., Singapore). The amplicon was sent to sequencing services company ( $1^{\text {st }}$ Base) in Singapore to be sequenced. Sequences were analyzed using Sequence Scanner 2 (Applied Biosystem) and BioEdit. The complete sequence of 16S rRNA was then compared with GenBank database using BLAST nucleotide (http://www.ncbi.nlm.nih. gov/BLAST/Blast.cgi) to identify the species of the bacterial isolate.

\section{Qualitative antimicrobial test: Well diffusion method}

The method was done according to Irulandi et al. [11], with some modifications. Nutrient agar (Merck) inoculated with $1 \%$ of isolate liquid culture $(O D=0.1)$ was poured on a Petri dish and allowed to solidify. The wells with diameter $7.0 \mathrm{~mm}$ were then made on the agar plates. Serial dilutions of $P$. scutellaria extracts (hexane, ethyl acetate, and methanol fractions) were made with concentration of 400, 200, 100,50 , and $25 \mathrm{mg} / \mathrm{ml}$, using DMSO as diluents. The extracts were then put into the wells with a micropipette. Each well was filled with $20 \mu \mathrm{l}$ extract. The plates were incubated at $37^{\circ} \mathrm{C}$ for $24 \mathrm{~h}$, and the diameter of the formed clear zone was measured. For each fraction and each concentration, four repetitions were done. As negative control $20 \mu \mathrm{l}$ pure DMSO was used, while the positive control was $20 \mu \mathrm{l} \mathrm{of} 1 \mathrm{mg} / 4 \mathrm{ml}$ tetracycline solution in distilled water.

\section{Quantitative antimicrobial test: Colony-forming unit (CFU) assay}

Extracts of $P$. scutellaria (hexane, ethyl acetate, and methanol fractions) were prepared in a concentration of 225, 250, and $400 \mathrm{mg} / \mathrm{ml}$, respectively. $50 \mu \mathrm{l}$ of each fraction was added into $450 \mu \mathrm{l}$ of liquid isolated bacteria culture $(O D=0.1)$. The mixtures were incubated at $37^{\circ} \mathrm{C}$ for $15 \mathrm{~min}$. Serial dilution of the mixtures was made using nutrient broth (Merck) as diluents and then spread on nutrient agar (Merck) plates. The plates were incubated at $37^{\circ} \mathrm{C}$ for $24 \mathrm{~h}$. The number of bacterial colonies formed for each dilution of the mixtures was counted using the CFU [13].

\section{RESULTS}

Isolation of bacteria found in the donor's armpit produced several bacteria types. Guided by the antibacterial activity of the P. scutellaria extract assays, Acinetobacter sp. bacteria were isolated from the donor's armpit. The identification of Acinetobacter sp. was mainly based on the molecular identification of the rRNA since the biochemical tests were not conclusive. Acinetobacter sp. found in the armpit of donor was tested against the extract of $P$. scutellaria (hexane, ethyl acetate, and methanol fractions) using well diffusion technique, which is mainly a qualitative test. The concentrations of the extracts were varied for each fraction. The experiments were repeated four times for each fraction and extract concentration. The results are shown in Table 1.

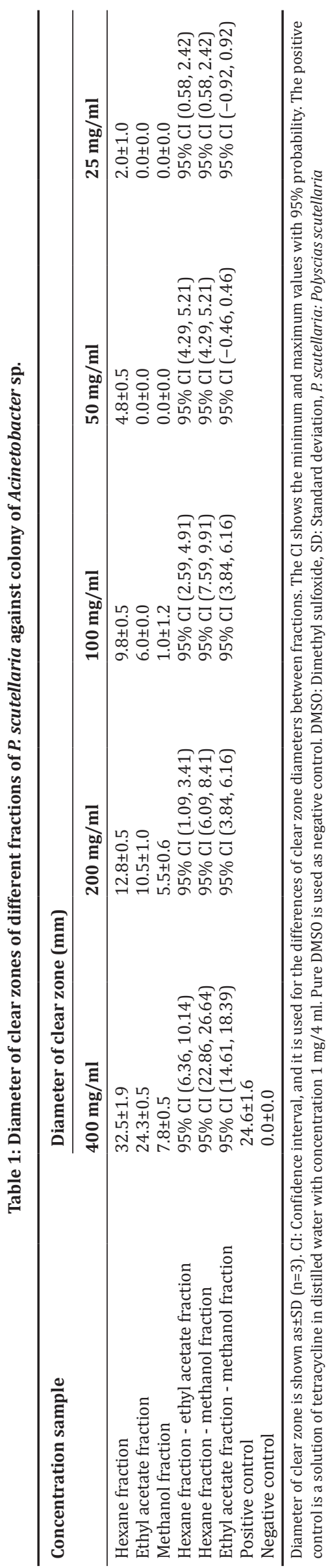


As seen in Table 1, for all concentrations, hexane fraction exhibited the largest diameter of clear zone followed by ethyl acetate and methanol consecutively. The clear zone diameters of each fraction for concentrations $400 \mathrm{mg} / \mathrm{ml}, 200 \mathrm{mg} / \mathrm{ml}$, and $100 \mathrm{mg} / \mathrm{ml}$ were verified to be different statistically by observing that the $95 \%$ confidence intervals (CIs) of the differences between the fractions did not include zero. The $\mathrm{CI}$ analysis also showed that for concentration $50 \mathrm{mg} / \mathrm{ml}$ and $25 \mathrm{mg} / \mathrm{ml}$, the clear-zone diameters of fraction hexane were different to those of ethyl acetate and methanol fractions, but for these concentrations, there were no differences for ethyl acetate and methanol fractions (CIs include zero). To measure the capability of each fraction in inhibiting the growth of Acinetobacter sp., quantitative analysis was also performed using the CFU assay. The results were displayed in Table 2. In the CFU test, serial dilutions of extract-containing bacterial culture were prepared with the different concentration of each fraction, guided by the results obtained from the qualitative analysis (presented in Table 1). DMSO was used as a control to count the number of bacteria without the addition of extract fraction. The results showed that both hexane and ethyl acetate fractions could inhibit the growth of bacteria by decreasing about 6 log cycles of Acinetobacter sp. to the control $\left(\sim 10^{8}\right.$ bacteria for control compared to $\sim 10^{2}$ bacteria for hexane and ethyl acetate fractions, Table 2). On the other hand, methanol fraction could not inhibit the growth of Acinetobacter sp., since the number of bacteria presents in the extract-containing media was still comparable to that of control.

\section{DISCUSSION}

Although well diffusion method resulted in qualitative data, the diameter of clear zone could indicates the strength of antibacterial activities of the extract. Higher concentration of the extract would form larger diameter of the clear zone. However, low extract concentration might not be enough to exhibit any clear zone, which means no antibacterial activity. For ethyl acetate and methanol fractions, the minimum concentration that showed antibacterial activity was between $100 \mathrm{mg} / \mathrm{ml}$ and $50 \mathrm{mg} / \mathrm{ml}$. Based on the diameter of the clear zone formed by hexane and ethyl acetate fraction $(>20 \mathrm{~mm})$, the antimicrobial activity of both fractions at concentration $400 \mathrm{mg} / \mathrm{ml}$ could be categorized as very strong according to the classification presented in a study of [14].

The diameter of the clear zone for the most potent fraction, hexane, was still smaller than the positive control tetracycline for concentration smaller than $400 \mathrm{mg} / \mathrm{ml}$. However, tetracycline is a problematic antibiotic which has a lot of side effects to humans, such as the possibility to stain teeth, cause hepatitis, skin hyper photosensitivity, and mitochondrial toxicity [15]. An experiment was done in this research using ampicillin as a positive control, but there was no clear zone formed, showing that Acinetobacter sp. bacteria are resistant to ampicillin. This indicated that $P$. scutellaria extracts have the possibility to become an alternative antibacterial agent against Acinetobacter sp.

In quantitative analysis, even though both hexane and ethyl acetate fractions exhibited similar inhibition toward the growth of Acinetobacter sp., the concentration used for hexane fraction was lower (225 mg/ ml) compared to ethyl acetate fraction $(250 \mathrm{mg} / \mathrm{ml})$.

Table 2: Quantitative analysis results of different fractions of P. scutellaria extracts

\begin{tabular}{lll}
\hline Sample & $\begin{array}{l}\text { Concentration } \\
(\mathbf{m g} / \mathbf{m l})\end{array}$ & $\begin{array}{l}\Sigma \text { cells } \\
\mathbf{( C F U / m l )}\end{array}$ \\
\hline Control (DMSO) & $\mathrm{N} / \mathrm{A}$ & $2.6 \times 10^{8}$ \\
Hexane fraction & 225 & $8.8 \times 10^{2}$ \\
Ethyl acetate fraction & 250 & $5.5 \times 10^{2}$ \\
Methanol fraction & 400 & $1.4 \times 10^{8}$ \\
\hline
\end{tabular}

N/A: Not available, CFU: Colony-forming unit, DMSO: Dimethyl

sulfoxide, $P$. scutellaria: Polyscias scutellaria
This means to obtain the similar inhibitory effect, the amount of hexane fraction used would be lower than ethyl acetate fraction. Previous research reported that $P$. scutellaria extract contains flavonoids, tannin, terpenoids, and saponin [16]. Nevertheless, further research is needed to isolate and elucidate the active compound for antibacterial activity in P. scutellaria extract.

\section{CONCLUSION}

P. scutellaria Fosberg showed the potential antibacterial activity against Acinetobacter sp. which was isolated from the human armpit. Both hexane and ethyl acetate fractions of $P$. scutellaria Fosberg extract indicated very strong inhibition (diameter of clear zone was higher than $20 \mathrm{~mm}$ at concentration $400 \mathrm{mg} / \mathrm{mL}$ ) against Acinetobacter sp. Furthermore, quantitative analysis exhibited that $225 \mathrm{mg} / \mathrm{ml}$ of hexane fraction and $250 \mathrm{mg} / \mathrm{ml}$ of ethyl acetate fraction could decrease Acinetobacter sp. cells of $6 \log$ cycles, whereas $400 \mathrm{mg} / \mathrm{ml}$ of methanol fraction could not decrease the number of Acinetobacter sp.

\section{ACKNOWLEDGMENTS}

The authors would like to thank the Ministry of Research and High Education, Republic of Indonesia in the form of Hibah Dosen Pemula No. 211/LPPM-UPH/VI/2017 for the support. Many thanks also to Advanced and Fundamental Biology Laboratorium, Department of Biology and Quality Control Laboratorium, Department of Food Technology, Universitas Pelita Harapan.

\section{AUTHORS' CONTRIBUTIONS}

Dela Rosa conceptualized and designed the study, advised on the data analysis and interpretation, prepared the draft of the manuscript, and reviewed the manuscript; Yunitawaty Halim advised on the data analysis and interpretation and reviewed the manuscript; Natania, advised on the data analysis and interpretation and reviewed the manuscript; Marcelia Sugata assisted in data collection and drafting the manuscript and reviewed the manuscript; Ariela Samantha assisted in data collection and reviewed the manuscript.

\section{CONFLICTS OF INTEREST}

Authors declare that there are no conflicts of interest.

\section{REFERENCES}

1. Nugraha AS, Keller PA. Revealing indigenous Indonesian traditional medicine: Anti-infective agents. Nat Prod Commun 2011;6:1953-66.

2. Wulandari L, Retnaningtyas Y, Nuri N, Lukman H. Analysis of flavonoid in medicinal plant extract using infrared spectroscopy and chemometrics. J Anal Methods Chem 2016;2016:1-6.

3. Dalimartha S. Atlas Tumbuhan Obat Indonesia. Jakarta: Trubus Agriwidya; 1999.

4. Raina MH. Ensiklopedi Tanaman Obat untuk Kesehatan. Yogyakarta: Absolut; 2011.

5. Fredrich E, Barzantny H, Brune I, Tauch A. Daily battle against body odor: Towards the activity of the axillary microbiota. Trends Microbiol 2013;21:305-12.

6. Grice EA, Segre JA. The skin microbiome. Nat Rev Microbiol 2011;9:244-53.

7. Manchanda V, Sanchaita S, Singh N. Multidrug resistant acinetobacter. J Glob Infect Dis 2010;2:291-304.

8. Roca I, Espinal P, Vila-Farrés X, Vila J. The Acinetobacter baumannii oxymoron: Commensal hospital dweller turned pan-drug-resistant menace. Front Microbiol 2012;3:148.

9. Perez F, Hujer AM, Hujer KM, Decker BK, Rather PN, Bonomo RA, et al. Global challenge of multidrug-resistant Acinetobacter baumannii. Antimicrob Agents Chemother 2007;51:3471-84.

10. Poulakou G, Bassetti M, Righi E, Dimopoulos G. Current and future treatment options for infections caused by multidrug-resistant gramnegative pathogens. Future Microbiol 2014;9:1053-69.

11. Irulandi K, Geetha S, Mehalingam P. Antimicrobial activity of selected Indian folk medicinal plants: Myristica fatua, Alstonia boonei, Helicteres isora, Vitex altissima, and Atalantia racemosa. Asian J Pharm Clin Res 2017;10:277-80. 
12. Karim R, Mahmud MN, Hakim MA. Production of bacteriocin like substances as antipathogenic metabolites by Staphylococcus warneri isolated from healthy human skin. Univ J Micr Res 2017;5:40-8.

13. Sangwan P, Kumar H. Synthesis, characterization, and antibacterial activities of chromium oxide nanoparticles against Klebsiella pneumonia. Asian J Pharm Clin Res 2017;10:206-9.

14. Davis WW, Stout TR. Disc plate method of microbiological antibiotic assay. I. Factors influencing variability and error. Appl Microbiol
1971;22:659-65.

15. Chatzispyrou IA, Held NM, Mouchiroud L, Auwerx J, Houtkooper RH. Tetracycline antibiotics impair mitochondrial function and its experimental use confounds research. Cancer Res 2015;75:4446-9

16. Sari Y, Wardatun S, Miranti M. Uji toksisitas dan aktivitas antioksidan minuman jelly daun Mangkokan (Nothopanax scutellarium Merr.). Bogor: Universitas Pakuan; 2011. 